\title{
PENGARUH KOMPOSISI FACE-CORE TERHADAP SIFAT FISIK DAN MEKANIS ORIENTED STRAND BOARD DARI BAMBU DAN ECENG GONDOK
}

\author{
Effects of Face-Core Composition on Physical and Mechanical Properties of Oriented Strand Board Made \\ From Bamboo and Water Hyacinth \\ Sahriyanti Saad ${ }^{1 \bowtie}$ dan Hilal ${ }^{2}$
}

${ }^{1}$ Lab. Pemanfaatan dan Pengolahan Hasil Hutan, Fakultas Kehutanan Universitas Hasanuddin,

Jl. Perintis Kemerdekaan Km. 10 Tamalanrea, Makassar 90245

${ }^{2}$ Alumni Fakultas Kehutanan Universitas Hasanuddin

\begin{abstract}
The effect of particle composition made of bamboo and water hyacinth on the dimensional stability and mechanical properties of resulted oriented strand boards (OSB) were investigated. Three layered boards were made from bamboo and water hyacinth in which bamboo strand was used as face/back layer and water hyacinth strand was used as core layer. The boards were manufactured using three levels of bamboo and water hyacinth compositions (50:50, 60:40 and 70:30) with $6 \%$ isocyanate based on the strand oven dry weight. The results showed that dimensional stability of the OSB decreased with the increase of composition of water hyacinth strand on core layer. A higher composition of bamboo strand as face/back layer compared to water hyacinth strand resulted in increased modulus of elasticity and internal bond strength, but decreased the modulus of rupture. The bamboo and water hyacinth composition of 70:30 compositions showed better properties than other compositions.
\end{abstract}

Key words: Bamboo, water hyacinth, composition, OSB

\section{PENDAHULUAN}

Berbagai jenis produk kayu olahan terutama panel-panel kayu atau komposit kayu yang menggunakan berbagai geometri partikel dapat diproduksi dengan mengganti bahan baku kayu dengan bahan-bahan berlignoselulosa lainya. Oriented Strand Board (OSB) yang digolongkan sebagai papan partikel dan digunakan untuk berbagai komponen bangunan dan mebel dapat diproduksi dengan menggunakan partikel dari bahan lignoselulosa bukan kayu.

Bahan berlignoselulosa selain kayu yang potensil digunakan untuk memproduksi OSB yaitu bambu ater (Gigantochloa ater (Hassk.) Kurz ex Munro) dan eceng gondok (Eichhornia crassipes). Bambu ater dan eceng gondok tersebar di berbagai daerah di Indonesia sehingga sangat berpotensi

\footnotetext{
Diterima: 7 Mei 2012; Disetujui: 4 Juli 2012

$\square$ Penulis korespondensi (corresponding author): arie_tanti@yahoo.com
}

untuk dijadikan bahan baku OSB. Selain itu, kedua jenis bahan baku ini memiliki kandungan selulosa yang cukup tinggi sehingga dapat digunakan sebagai bahan baku OSB. Bahan pengikat dari pembuatan OSB yang banyak dikembangkan saat ini adalah perekat isosianat. Keunikan perekat isosianat adalah dapat digunakan pada variasi suhu yang luas, tahan air, panas, cepat kering, $\mathrm{pH}$ netral dan kedap terhadap solvent (pelarut organik). Perekat ini juga memiliki daya guna yang luas untuk merekatkan berbagai macam kayu ke kayu.

Untuk mengetahui efektifitas penggunaan bambu ater dan eceng gondok yang disatukan oleh perekat isosianat menjadi OSB maka perlu dilakukan penelitian untuk melihat berapa besar pengaruh komposisi bahan baku partikel tersebut terhadap sifat fisik dan mekanis OSB yang di hasilkan. Pengaruh komposisi bahan baku partikel terhadap sifat fisik dan mekanik OSB dapat diketahui dengan membuat tiga tipe papan dengan komposisi bahan partikel yang berbeda pada bagian face-core. 
Tabel 1. Sifat Fisik OSB

\begin{tabular}{|c|c|c|c|c|c|c|c|c|}
\hline \multirow{2}{*}{ Tipe OSB } & \multirow{2}{*}{$\begin{array}{l}\text { Kerapatan } \\
\left(\mathrm{g} \mathrm{cm}^{-3}\right)\end{array}$} & \multirow{2}{*}{$\begin{array}{c}\text { Kadar Air } \\
(\%)\end{array}$} & \multicolumn{2}{|c|}{ Pengembangan Tebal (\%) } & \multicolumn{2}{|c|}{ Pengembangan Linear (\%) } & \multicolumn{2}{|c|}{ Daya Serap Air (\%) } \\
\hline & & & 2 jam & 24 jam & 2 jam & 24 jam & 2 jam & 24 jam \\
\hline$A$ & 0,48 & 18,36 & 27,2 & 31,66 & 0,62 & 1,94 & 42,79 & 91,71 \\
\hline B & 0,52 & 17,95 & 5,46 & 9,01 & 0,79 & 1,34 & 28,23 & 71,74 \\
\hline C & 0,66 & 13,78 & 6,25 & 18,42 & 1,46 & 1,58 & 16,36 & 58,02 \\
\hline
\end{tabular}

\section{METODE PENELITIAN}

Bahan yang digunakan dalam penelitian ini adalah strand eceng gondok dengan kadar air 3-6 $\%$ yang berukuran panjang $60-70 \mathrm{~mm}$, lebar 20-25 $\mathrm{mm}$. Strand bambu ater tanpa buku dan kulit dengan kadar air 3-7 \% yang berukuran sama dengan strand eceng gondok serta perekat isosianat tipe H3M dengan solid content $99,79 \%$.

\section{Pembuatan lembaran OSB}

Strand dicampur dengan perekat dengan cara disemprotkan dimana kadar perekat yang digunakan sebesar $6 \%$ dari berat strand merujuk pada penelitian Saad (2008). Papan dibuat 3 lapis dimana pada bagian face adalah strand bambu dan bagian core adalah strand eceng gondok dengan arah strand pada lapisan face dan core saling tegak lurus. Kerapatan sasaran $0,70 \mathrm{~g} \mathrm{~cm}^{-3}$ dengan ukuran $30 \mathrm{~cm} \times 30 \mathrm{~cm} \times 1 \mathrm{~cm}$. Papan dibuat 3 tipe berdasarkan perbandingan berat strand pada face dan core dengan berat strand untuk satu sampel papan dalam persen (\%) yaitu 50:50 (A), 60:40 (B) dan 70:30 (C). Lembaran dikempa dengan suhu 150 ${ }^{\circ} \mathrm{C}$, tekanan spesifik $25 \mathrm{~kg} \mathrm{~cm}^{-2}$ selama 5 menit.

\section{Pengujian Sifat Fisik dan Mekanis OSB}

Pengujian sifat fisik dan mekanis OSB dilakukan berdasarkan Japan Industrial Standard (JIS) A 5908-2003. Sifat fisik dan mekanis OSB yang diuji meliputi: kerapatan, kadar air, daya serap air, pengembangan tebal dan pengembangan linier, keteguhan patah (MOR), modulus elastisitas (MOE), internal bond dan kuat pegang sekrup.

\section{HASIL DAN PEMBAHASAN}

\section{Sifat fisik OSB}

Hasil pengujian terhadap sifat fisik contoh uji OSB disajikan pada Tabel 1. Tabel 1 menunjukkan bahwa nilai kerapatan rata-rata contoh uji OSB memenuhi standar pada semua perlakuan berdasarkan JIS A 5908-2003. Kerapatan sasaran yang tidak tercapai lebih disebabkan oleh ketebalan papan yang dihasilkan lebih besar dari batas yang ditetapkan yakni $1 \mathrm{~cm}$. Beberapa OSB yang dihasilkan memiliki kerapatan yang berbeda disebabkan oleh bahan baku strand yang digunakan dimana untuk strand eceng gondok yang memiliki kerapatan yang sangat rendah bila dibandingkan dengan strand bambu pada proporsi yang sama. Akibatnya, papan yang menggunakan eceng gondok yang lebih banyak memiliki kerapatan yang lebih rendah. Menurut Maloney (1993), kerapatan sangat memengaruhi hampir semua sifat papan komposit.

Nilai kadar air rata-rata contoh uji OSB dari nilai tertinggi ke terendah masing-masing adalah 18,36 $\%$ pada komposisi $A ; 17,59 \%$ pada komposisi $B$ dan $13,78 \%$ pada komposisi C. Dalam JIS A 5908-2003 kadar air OSB ditetapkan sebesar 5-13 \% sehingga dapat dilihat bahwa kadar air OSB tidak memenuhi standar pada semua perlakuan. Hal ini disebabkan sifat eceng gondok yang porous sehingga pada saat pengkondisian selama 2 minggu strand eceng gondok mengalami kenaikan kadar air yang lebih cepat. Menurut Kurniawan \& Ahmad (2009), secara umum masih memungkinkan untuk menggunakan flake eceng gondok sampai taraf $30 \%$, kecuali untuk sifat pengembangan tebal penggunaan flake eceng gondok pada papan komposit optimum sampai taraf $20 \%$. Sedangkan penggunaan tipe lapisan permukaan tergantung tujuan yang ingin dicapai.

OSB yang dihasilkan memiliki kadar air yang variatif diduga diakibatkan oleh kadar air pada tiap strand yang digunakan juga bervariasi dimana pengeringan strand dalam jumlah yang banyak menjadikan panas yang diberikan tidak terdistribusi merata dalam tumpukan strand. Peningkatan kadar air pada strand juga diakibatkan oleh keberadaan strand eceng gondok yang lebih mudah menyerap air. 
Table 2. Sifat Mekanis OSB

\begin{tabular}{|c|c|c|c|}
\hline \multirow{2}{*}{ Sifat Mekanis } & \multicolumn{3}{|c|}{ Tipe OSB } \\
\hline & $A$ & $B$ & C \\
\hline MOE (kering) $\left(\mathrm{kgf} \mathrm{cm}^{-2}\right)$ sejajar panjang & $40.412,54$ & $75.749,85$ & $107.398,88$ \\
\hline MOE (kering) $\left(\mathrm{kgf} \mathrm{cm}^{-2}\right.$ ) sejajar lebar & $8.434,85$ & $12.109,04$ & $63.264,70$ \\
\hline MOE (basah) $\left(\mathrm{kgf} \mathrm{cm}^{-2}\right)$ sejajar panjang & $21.954,31$ & $36.763,02$ & $77.138,09$ \\
\hline MOE (basah) $\left(\mathrm{kgf} \mathrm{cm}^{-2}\right)$ sejajar lebar & $6.380,24$ & $13.453,22$ & $54.088,54$ \\
\hline MOR (kering) $\left(\mathrm{kgf} \mathrm{cm}^{-2}\right)$ sejajar panjang & 114,48 & 112,41 & 107,37 \\
\hline MOR (kering) $\left(\mathrm{kgf} \mathrm{cm}^{-2}\right)$ sejajar lebar & 82,15 & 74,94 & 149,85 \\
\hline MOR (basah) $\left(\mathrm{kgf} \mathrm{cm}^{-2}\right)$ sejajar panjang & 75,66 & 84,31 & 63,75 \\
\hline MOR (basah) $\left(\mathrm{kgf} \mathrm{cm}^{-2}\right)$ sejajar lebar & 88,63 & 66,29 & 63,84 \\
\hline Internal bond $\left(\mathrm{kgf} \mathrm{cm}^{-2}\right)$ & 0,63 & 0,61 & 2,94 \\
\hline Kuat pegang sekrup (kgf) & 37,39 & 39,09 & 46,91 \\
\hline
\end{tabular}

Hasil pengujian terhadap pengembangan tebal setelah perendaman selama 2 dan 24 jam pada contoh uji OSB menunjukkan bahwa nilai pengembangan tebal setelah perendaman selama 2 jam rata-rata contoh uji OSB berkisar 5,46-27,2 $\%$ dan pengembangan tebal setelah perendaman selama 24 jam rata-rata contoh uji OSB berkisar 9,01$31,66 \%$. Dalam JIS A 5908-2003, pengembangan tebal OSB ditetapkan maksimum $25 \%$ sehingga pengembangan tebal OSB yang dihasilkan memenuhi standar pada komposisi B dan C.

Persentase pengembangan tebal pada OSB dengan komposisi 50:50 menjadi lebih tinggi akibat komposisi eceng gondok dengan jumlah strand yang banyak memungkinkan perekat tidak terlabur merata menutupi permukaan seluruh strand dan mengakibatkan banyak rongga yang mudah menyerap dan terisi oleh air. Variasi pengembangan tebal OSB yang dihasilkan juga diakibatkan oleh sifat strand eceng gondok yang menyerupai karet busa yang bila menyerap air maka pengembangannya sangat tinggi. Pengembangan juga tidak terjadi seiring pertambahan strand eceng gondok terjadi akibat masa pengkondisian pada contoh uji OSB yang tidak sama pada setiap contoh uji.

Hasil pengujian terhadap pengembangan linear setelah perendaman selama 2 dan 24 jam pada contoh uji OSB menunjukkan bahwa nilai pengembangan linear setelah perendaman selama 2 jam rata-rata contoh uji OSB berkisar 0,26$1,46 \%$ dan nilai pengembangan linear setelah perendaman selama 24 jam rata-rata contoh uji OSB berkisar 1,34-1,94 \%. Dalam JIS A 5908-2003, pengembangan tebal OSB tidak dipersyaratkan.
Pengembangan linear adalah besaran yang menyatakan pertambahan panjang contoh uji dalam persen terhadap dimensi awal. Setelah contoh uji direndam dalam air pada suhu kamar selama 2 dan 24 jam (Sutrisno, 2001). Pengembangan linier pada OSB hanya memiliki perubahan yang sedikit. Permasalahan yang terjadi yakni strand yang digunakan berbeda dalam satu papan. Perubahan dimensi antara partikel yang berbeda menimbulkan gaya saling menahan.

Hasil pengujian terhadap daya serap air setelah perendaman selama 2 dan 24 jam pada contoh uji OSB menunjukkan bahwa nilai daya serap air setelah perendaman selama 2 jam rata-rata contoh uji OSB berkisar 16,36-42,79 \% dan setelah perendaman selama 24 jam rata-rata contoh uji OSB berkisar 58,02-91,71\%. Banyaknya komposisi strand eceng gondok dan bambu ater pada OSB sangat memengaruhi kemampuan OSB menyerap air. Terjadinya penyerapan yang tinggi pada OSB dengan ratio 50:50 diakibatkan komposisi eceng gondok yang lebih banyak dari pada tipe papan yang lainnya. Berbeda dengan OSB yang dihasilkan dengan rasio 70:30 dimana komposisi eceng gondoknya lebih sedikit.

\section{Sifat Mekanis OSB}

Hasil pengujian sifat mekanis terhadap contoh uji OSB disajikan pada Tabel 2.

\section{Modulus Elastisitas (MOE)}

Tabel di atas menunjukkan bahwa nilai ratarata MOE dalam kondisi kering pada arah tekan 
sejajar panjang contoh uji OSB dari nilai tertinggi ke terendah adalah $107.398,88 \mathrm{kgf} \mathrm{cm}^{-2}$ pada komposisi C; $75.749,85 \mathrm{kgf} \mathrm{cm}^{-2}$ pada komposisi B dan $40.412,54 \mathrm{kgf} \mathrm{cm}^{-2}$ pada komposisi A. Sedangkan pada arah tekan sejajar lebar adalah $63.264,70 \mathrm{kgf}$ $\mathrm{cm}^{-2}$ pada komposisi C; $12.109,04 \mathrm{kgf} \mathrm{cm}^{-2}$ pada komposisi B dan $8.434,85 \mathrm{kgf} \mathrm{cm}^{-2}$ pada komposisi A. Dalam JIS A 5908-2003, nilai MOE dalam kondisi kering pada arah tekan sejajar panjang ditetapkan minimum $40.800 \mathrm{kgf}^{-2}$ sehingga OSB yang dihasilkan memenuhi standar pada komposisi $\mathrm{B}$ dan C. Sedangkan untuk JIS A 5908-2003 nilai MOE dalam kondisi kering pada arah sejajar lebar ditetapkan minimum $13.300 \mathrm{kgf} \mathrm{cm}^{-2}$ sehingga OSB yang dihasilkan memenuhi standar hanya pada komposisi C. Hal ini menunjukkan bahwa semakin banyak komposisi strand bambu pada face maka nilai MOE akan semakin tinggi. MOE merupakan sifat yang menunjukkan kekakuan papan. Semakin banyak strand bambu yang disusun pada face papan akan mengalami deformasi yang semakin kecil dan mengindikasikan papan itu semakin kaku.

Nilai MOE kering sejajar panjang lebih tinggi dari nilai MOE kering sejajar lebar. Hal ini disebabkan posisi strand bambu ater pada face yang jika diberi tekanan pada arah sejajar panjangnya akan lebih kaku dibandingkan jika diberi tekanan pada sejajar arah lebarnya. Adapun strand eceng gondok yang berada pada core yang mana pada pemberian tekanan sejajar lebarnya akan lebih cepat patah dibandingkan dengan pemberian tekanan pada arah sejajar arah panjangnya. Hal ini menunjukan sifat dan kekuatan bahan memengaruhi nilai MOE.

Nilai rata-rata MOE dalam kondisi basah pada arah tekan sejajar panjang contoh uji OSB dari nilai tertinggi ke terendah adalah 21.954,31 kgf $\mathrm{cm}^{-2}$ pada komposisi A; $36.763,02 \mathrm{kgf} \mathrm{cm}^{-2}$ pada komposisi B dan $77.138,09 \mathrm{kgf} \mathrm{cm}^{-2}$ pada komposisi C. Sedangkan pada arah tekan sejajar lebar adalah $54.088,54 \mathrm{kgf} \mathrm{cm}^{-2}$ pada komposisi A; $13.453,22 \mathrm{kgf}$ $\mathrm{cm}^{-2}$ pada komposisi B dan $6.380,24 \mathrm{kgf} \mathrm{cm}^{-2}$ pada komposisi C. Dalam JIS A 5908-2003, nilai MOE dalam kondisi basah pada arah sejajar panjang dan lebar tidak dipersyaratkan. Perendaman pada air mendidih selama 2 jam dan selanjutnya direndam pada air dingin selama 1 jam membuat nilai MOE pada sampel uji ini memiliki nilai yang kecil. Perlakuan tersebut dapat melemahkan ikatan perekat antar strand.

\section{Keteguhan Patah (MOR)}

Hasil pengujian terhadap MOR kering sejajar panjang dan lebar contoh uji OSB menunjukkan bahwa nilai MOR kering sejajar panjang rata-rata contoh uji OSB berkisar 114,48-107,37 $\mathrm{kgf}^{-2}$. Sedangkan nilai MOR basah sejajar lebar ratarata contoh uji OSB berkisar 6.380,24-54.088,54 $\mathrm{kgf} \mathrm{cm}^{-2}$. Dalam JIS A 5908-2003, nilai MOR dalam kondisi kering pada arah tekan sejajar panjang minimum $245 \mathrm{kgf} \mathrm{cm}^{-2}$ dan lebar minimum $102 \mathrm{kgf}$ $\mathrm{cm}^{-2}$. Dengan demikian OSB yang dihasilkan tidak memenuhi standar pada semua perlakuan tekan arah sejajar panjang sedangkan pada pengujian arah sejajar lebar yang memenuhi standar hanya pada komposisi $\mathrm{C}$.

Terjadi peningkatan nilai MOR pada arah sejajar panjang tiap penambahan strand bambu ater pada face dan pengurangan eceng gondok pada core akan tetapi penambahan tersebut tidak signifikan. Pada arah sejajar panjang nilai MOR dari komposisi $\mathrm{A}$ ke $\mathrm{C}$ semakin besar. sebaliknya pada arah tekan sejajar nilai MOR dari $A$ ke $C$ semakin kecil. Hal ini disebabkan papan diberi tekanan pada arah sejajar panjang pada strand bambu lebih kuat dari pada arah lebarnya dan arah tekanan sejajar panjang pada strand eceng gondok. Strand eceng gondok akan lebih kuat jika diberi tekanan terhadap arah panjangnya.

Hasil pengujian terhadap MOR basah sejajar panjang dan lebar contoh uji OSB menunjukkan bahwa nilai rata-rata MOR dalam kondisi basah pada arah sejajar panjang contoh uji OSB dari nilai tertinggi ke terendah adalah $84,31 \mathrm{kgf} \mathrm{cm}^{-2}$

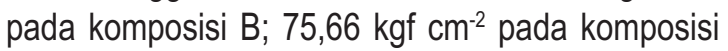
A dan $63,75 \mathrm{kgf} \mathrm{cm}^{-2}$ pada komposisi C. Sedangkan pada arah sejajar lebar adalah $88,63 \mathrm{kgf} \mathrm{cm}^{-2}$ pada komposisi A; 66,29 $\mathrm{kgf} \mathrm{cm}^{-2}$ pada komposisi $B$ dan $63,84 \mathrm{kgf} \mathrm{cm}^{-2}$ pada komposisi C. Dalam JIS A 5908-2003, nilai keteguhan patah dalam kondisi basah pada arah tekan sejajar panjang ditetapkan minimum $122 \mathrm{kgf} \mathrm{cm}^{-2}$ dan pada tekan sejajar lebar ditetapkan minimum $51 \mathrm{kgf} \mathrm{cm}^{-2}$. Dengan demikian, OSB yang dihasilkan tidak memenuhi standar pada semua perlakuan tekan arah sejajar panjang dan memenuhi standar pada semua perlakuan tekan arah sejajar lebar. Setiap penambahan strand bambu ater pada face maka terjadi peningkatan pada MOR pada arah sejajar panjang dalam kondisi basah. Hal ini dipengaruhi oleh arah sejajar panjang pada strand bambu. Sedangkan pada arah tekan 
sejajar lebar terjadi penurunan nilai MOR pada setiap penambahan strand bambu ater pada face. Hal ini dipengaruhi arah sejajar panjang pada strand eceng gondok dimana strand eceng gondok akan lebih kuat jika diberi tekanan terhadap arah panjangnya.

\section{Internal Bond}

Hasil pengujian terhadap internal bond contoh uji OSB menunjukkan bahwa nilai internal bond ratarata contoh uji OSB dari nilai tertinggi ke terendah masing-masing adalah $2,94 \mathrm{kgf} \mathrm{cm}^{-2}$ pada komposisi C; 0,63 kgf cm-2 pada komposisi A dan 0,61 kgf $\mathrm{cm}^{-2}$ pada komposisi B. Dalam JIS A 5908-2003, internal bond OSB ditetapkan minimum 3,10 kgf $\mathrm{cm}^{-2}$ sehingga internal bond OSB tidak memenuhi standar pada semua komposisi. Semakin banyak porsi eceng gondok maka semakin lemah kekuatan rekat OSB. Fenomena ini juga dapat dipengaruhi oleh kerapatan pada lapisan eceng gondok yang rendah pada OSB dengan komposisi 60:40 dan 50:50. Bowyer et al. (2003) menyatakan keteguhan rekat mengindikasikan kekuatan ikatan antar partikel dan merupakan pengujian yang penting untuk pengendalian kualitas karena menunjukkan kemampuan pencampuran perekat, pembentukan lembaran dan proses pengempaan.

\section{Kuat Pegang Sekrup}

Hasil pengujian terhadap kuat pegang sekrup contoh uji OSB menunjukkan bahwa kuat pegang sekrup rata-rata contoh uji OSB dari nilai tertinggi ke terendah masing-masing adalah 46,91 kgf pada komposisi C; 39,09 kgf pada komposisi B dan 37,39 kgf pada komposisi A. Dalam JIS A 5908-2003, kuat pegang sekrup OSB ditetapkan minimum 49,02 kgf sehingga dapat dilihat bahwa kuat pegang sekrup OSB tidak memenuhi standar pada semua komposisi.

Kuat pegang sekrup cenderung meningkat dengan berkurangnya porsi eceng gondok pada core dan bertambahnya porsi bambu pada face. Eceng gondok tidak memiliki susunan sel yang solid dan saling merekat sehingga pada saat pengempaan memungkinkan banyak bagian pada
OSB yang memeliki kerapatan rendah sehingga tidak terlalu efektif dalam memegang sekrup. Menurut Maloney (1993), bagian permukaan yang terlebih dahulu mengalami pemanasan akan mengalami plastisasi yang diikuti dengan proses densifikasi mengakibatkan kerapatan papan pada bagian permukaan lebih tinggi. Nilai kuat pegang sekrup yang memadai sangat penting dalam pengerjaan papan seperti dalam pembuatan furniture atau pelapis lantai yang membutuhkan sekrup.

\section{KESIMPULAN}

Komposisi bambu ater dan eceng gondok memengaruhi sifat fisik dan mekanis OSB kecuali pada pengembangan linear dan keteguhan patah MOR. Stabilitas dimensi, modulus elastisitas, dan internal bond OSB menurun dengan semakin banyaknya porsi strand bambu pada lapisan face. Dengan demikian, komposisi 70:30 antara strand bambu dan strand eceng gondok merupakan komposisi yang terbaik dalam untuk menghasilkan OSB dengan sifat fisik dan mekanis yang memadai.

\section{DAFTAR PUSTAKA}

Bowyer, J. L., R. Shmulsky and J. G. Haygreen. 2003. Forest Product and Wood Sience: an Introduction. 4th Ed. USA: Lowa State Press A Blackwell Publ.

[JSA] Japanese Standards Association. 2003. Particleboards. Japanese Industrial Standard (JIS) A 5908-2003. Japan.

Kurniawan dan A. Ahmad. 2009. Pengaruh Tipe Lapisan Permukaan dan Komposisi Flake Eceng Gondok (Eichornia crassipes) terhadap Sifat Fisis Mekanis Papan Komposit. http://repository.ipb.ac.id/handle/123456789/16231. [diakses tanggal 6 Januari 2012].

Maloney, T. M. 1993. Modern Particle Board and Dry Procces Fiber Board Manufactury. Miller Freeman, Inc. Edisi Revisi. San Francisco USA : Miller Freeman Inc.

Saad, S. 2008. Pengembangan Oriented Strand Board dari Bambu Betung Dendrocalamus asper (schult.f.) Backer ex Heyne). [Thesis] Sekolah Pasca Sarjana IPB. Bogor.

Sutrisno. 2001. Hubungan antara Keteguhan Geser Tekan dengan Keteguhan Rekat Internal Papan Untai. Bahan Makalah Falsafah Sains (PPs 702) Program Pasca Sarjana/S3 Institusi Pertanian Bogor. 